MONKEY BUSINESS THEATRE 
THE LINDA SCHELE SERIES IN MAYA AND PRE-COLUMBIAN STUDIES

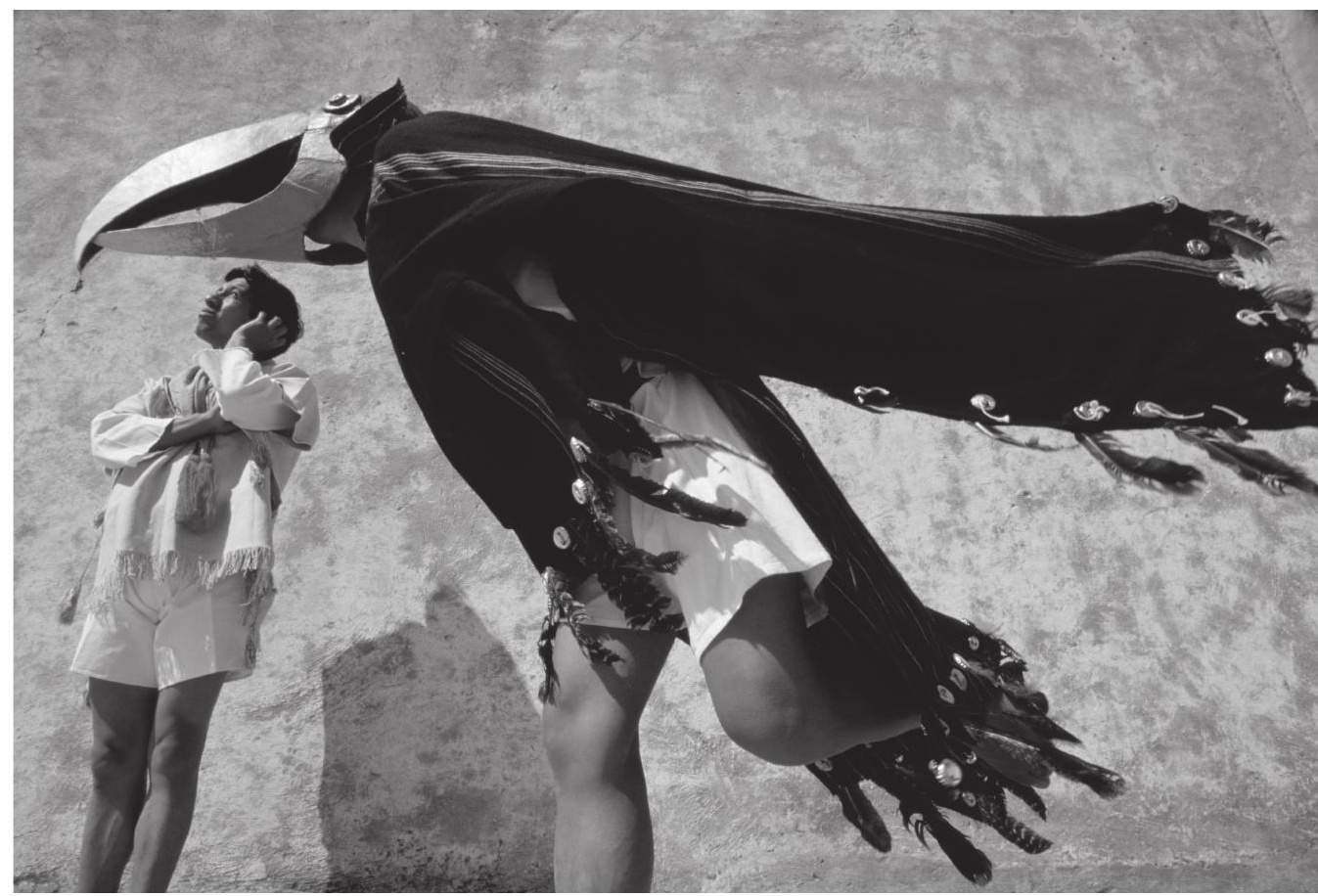

The Loafer and the Buzzard, 1977. Photo copyright (C Macduff Everton 


\section{Monkey Business Theatre}

BY ROBERT M. LAUGHLIN AND SNA JTZ'IBAJOM 
This series was made possible through the generosity of WILLIAM C. NOWLIN, JR., AND BETTYE H. NOWLIN, the National Endowment for the Humanities, and various individual donors.

COPYRIGHT (C) 2008 BY THE UNIVERSITY OF TEXAS PRESS

All rights reserved

Printed in the United States of America

First edition, 2008

Requests for permission to reproduce material from this work should be sent to: PERMISSIONS

University of Texas Press

P.O. Box 7819

Austin, TX 78713-7819

www.utexas.edu/utpress/about/bpermission.html

(2) The paper used in this book meets the minimum requirements of ANSI/NISO Z39.48-1992 (R1997) (Permanence of Paper).

\section{LIBRARY OF CONGRESS CATALOGING-IN-PUBLICATION DATA}

Laughlin, Robert M.

Monkey Business Theatre / by Robert M. Laughlin and Sna Jtz'ibajom. — 1st ed. p. cm. - (The Linda Schele Series in Maya and pre-Columbian studies) Includes bibliographical references and index.

ISBN 978-0-292-71759-6 (cl. : alk. paper)

1. Tzotzil drama. 2. Tzeltal drama. 3. Puppet theater-Mexico. 4. Mexican drama.

5. Teatro Lo'il Maxil. I. Sna Jtz' ibajom. II. Teatro Lo'il Maxil. III. Title.

PM4466.Z77L38 2008

$897^{\prime} .428208-\mathrm{dc} 22$ 


\section{DEDICATED \\ TO THE \\ PRESENT \\ AND \\ PAST \\ MEMBERS \\ OF}

SNA JTZ'IBAJOM 
THIS PAGE INTENTIONALLY LEFT BLANK 